\title{
Serum CA 19-9 Low
}

National Cancer Institute

\section{Source}

National Cancer Institute. Serum CA 19-9 Low. NCI Thesaurus. Code C162049.

The amount of cancer antigen 19-9 present in a serum sample is low. 